\title{
A NEW APPROACH FOR ASSESSMENT OF NARCOTIC PHYSICAL DEPENDENCE USING URINARY SEX-DEPENDENT LOW MOLECULAR WEIGHT PROTEINS IN MALE RATS
}

\author{
Isamu AKIBA, Hitoshi ENDOU*, Tsutomu SUZUKI, Saizo YANAURA and Fuminori SAKAI* \\ Department of Pharmacology. School of Pharmacy. Hoshi Univorsity. \\ Shinagawa-ku. Tokyo 142, Japan and *Department of Pharmacology. \\ Faculty of Medicine. University of Tokyo. Eunkyo-ku. Tokyo 113, Japan
}

Accepted October 25, 1982

\begin{abstract}
Attempts have been made to examine the relationship between urinary excretion of sex-dependent low molecular weight proteins found only in male rats (LMWP) and morphine physical dependence. Chronic administration of morphine produced a dose-related decrease in urinary LMWP excretion, which was correlated to the intensity of withdrawal signs including body weight loss and abnormal behaviors recognized after naloxone challenge. Furthermore, a statistically high correlation was obtained between the decrease in urinary LMWP excretion and the loss of body weight precipitated by naloxone challenge. LMWP was identified immunologically in the livers, kidneys, and sera using an antibody against purified LMWP. The serum level of LMWP was increased rapidly following bilateral nephrectomy. After chronic treatment with morphine, the LMWP content in the livers, kidneys, and sera were decreased. These findings indicate that the decrease in urinary LMWP excretion induced by chronic administration of morphine can be a useful parameter to assess the development of physical dependence on narcotics on the peripheral level without requiring drug withdrawal and naloxone challenge. This decrease in urinary LMWP may be caused by the inhibition of LMWP synthesis in the liver.
\end{abstract}

There previously has been no report that demonstrates physical sign(s) in the narcoticdependent state without requiring drug withdrawal. Recently, we have introduced a physical sign that reflects the induction of narcotic physical dependence in male rats without requiring drug withdrawal and naloxone challenge $(1,2)$. The urinary excretion of sex-dependent low molecular weight proteins (LMWP), which exist only in male rats, was significantly decreased without marked changes in albumin excretion in animals having an induced physical dependence on typical and non-typical narcotics such as morphine, codeine and pethidine.

Urinary proteins detected in male rats have been investigated (3-6). Roy et al. (3) isolated a sex-dependent glycoprotein from male rat urine and named it $\alpha_{2 u}$-globulin, although the heterogeneity of sex-dependent proteins in male rats was described in further studies (4, 5). Moreover, Roy and Neuhaus (6) reported that the sex-dependent $\alpha_{2 u}$ globulin, a component of LMWP, was synthesized in the liver and excreted by the kidneys into the urine.

The present paper describes a relationship between the decrease in urinary LMWP excretion and the intensity of narcotic physical dependence in order to clarify whether the LMWP change can be a useful parameter with which to assess the development of physical dependence on the peri- 
pheral level without drug withdrawal and naloxone challenge. At the same time, a possible mechanism for the decrease in urinary LMWP excretion after chronic treatment with narcotics has been examined using purified LMWP.

\section{Materials and Methods}

1. Schedule of chronic morphine administration: Male Wistar strain rats, 7 weeks of age. were housed in individual metabolic cages and given food and water ad libitum. The animal room was artificially illuminated daily from 08:30 to 20:30 and maintained at $22 \pm 1{ }^{\circ} \mathrm{C}$. Body weight was checked daily between 16:30-17:00 during the experiment. Daily total food and water intake was calculated by weighing the food hopper and by measuring the volume of the water tank at the time of the body weight check, respectively. Animals were chronically administered 5 doses of morphine (0.0625, 0.125, 0.25. 0.5 and $1.0 \mathrm{mg} / \mathrm{g}$ food) for 7 days by the drug-admixed food method (1, 2, 7). Control rats received morphine-free food (CA-1 powder, Clea Japan Inc. Tokyo).

The assessment of physical dependence on morphine was carried out using withdrawal signs precipitated by naloxone (3.0 $\mathrm{mg} / \mathrm{kg}, \mathrm{s.c}$.) challenge $(8,9)$.

2. Method of analyzing urinary proteins: Twenty-four hr urine samples were collected one day prior to morphine administration and on the 7th day after the administration. The collected urine sample was thrice diluted with $50 \%$ glycerol, and $1 \mu$ of each diluted urine was used for the protein analysis. Urinary proteins were electrophoretically separated and quantitatively measured on $4-40 \%$ continuous gradient polyacrylamide gels in $5 u$ capillary tubes (10). Densitograms of each gel, stained with $0.2 \%$ coomassie blue, were made with a Joyce-Loebl microdensitometer. MK III CS. The densitometric areas of the separated proteins were quanti- tatively analyzed using purified rat albumin and LMWP as standard proteins. In order to correct for urine dilution and concentration. creatinine was used as a volume marker. A detailed description of this procedure has been reported elsewhere (1, 10).

3. Biosynthesis of specific antiserum against urinary LMWP: The pooled urine of male adult rats was first filtered and then concentrated with polyethyleneglycol and dialyzed with dialyzer tubing (Tomas, 3787 H45. M.W. cut off 3.500). The concentrated urine was dialyzed for $24 \mathrm{hr}$ with constant stirring against three changes of distilled water and then further dialyzed overnight against $10 \mathrm{mM}$ phosphate buffer, $\mathrm{pH} 7.4$. Gel filtration for the urinary proteins was performed with Sephadex G-100 in a $2.5 \times 50 \mathrm{~cm}$ column. LMWP identified by electrophoresis was dialyzed against distilled water and lyophilized.

Antiserum against the partially purified LMWP was prepared by immunizing male New Zealand white rabbits with the antigen combined with Freund's complete adjuvant (latron Laboratories). Each $1 \mathrm{mg}$ of the protein was injected intracutaneously into the foot pads twice in a two week interval. One week after the second injection, $1 \mathrm{mg}$ of the protein was intravenously injected into the $V$. auricularis as a booster. The serum containing antibodies was obtained via the carotid artery 7 days after the booster.

4. Identification of organ origin of the urinary LMWP: The double diffusion method by Ouchterlony (11) was carried out in 1\% agar gel. Since the cytosolic fraction of the homogenates from the liver and the kidney showed more intense precipitin lines more intense than those of the total homogenates. samples used as antigens were serum and cytosolic proteins extracted from the following organs $(105,000 \times \mathrm{g}$ supernatant): lung, spleen, liver, kidney, testis, seminal vesicle and ovary. The cytosolic extracts of male and 
female Wistar strain rats weighing 230$250 \mathrm{~g}$ were prepared by homogenizing tissues in $4.0 \mathrm{vol}$. of $10 \mathrm{mM}$ phosphate-buffered saline, $\mathrm{pH}$ 7.4. The protein concentration of the serum and cytosolic extracts was determined by the procedure of Lowry et al. (12)

5. Immunological determination of urinary LMWP after chronic treatment with morphine: Bilateral nephrectomy was performed under pentobarbital anesthesia in control animals and animals treated with morphine $(0.5 \mathrm{mg} / \mathrm{g}$ food) for 7 days. Serum samples were obtained by exsanguination at 0 and $6 \mathrm{hr}$ following the operation. The serum and cytosolic extracts of livers and kidneys were used for immunodiffusion studies. Control rats were given morphine-free food, but otherwise were treated the same as animals treated with the drug.

6. Statistical analysis: Statistical comparisons wore done using the Student's $t$-test.

\section{Results}

1. Naloxone challenge for the estimation of physical dependence on morphine: The average of daily morphine intake for 7 days was $5.29 \pm 0.07,10.58 \pm 0.18,21.49 \pm 0.42$, $38.19 \pm 0.67$ and $76.94 \pm 2.12$ ( $\mathrm{mg} / \mathrm{kg} / \mathrm{day})$ in animals treated with the drug at doses of $0.0625,0.125,0.25,0.5$ and $1.0 \mathrm{mg} / \mathrm{g}$ food. respectively.

Abnormal behaviors recognized in each group after naloxone (3.0 $\mathrm{mg} / \mathrm{kg}$, s.c.) administration are summarized in Table 1. Rats treated with morphine clearly showed dose-dependent withdrawal signs including diarrhea, irritability. vocalization and aggression.

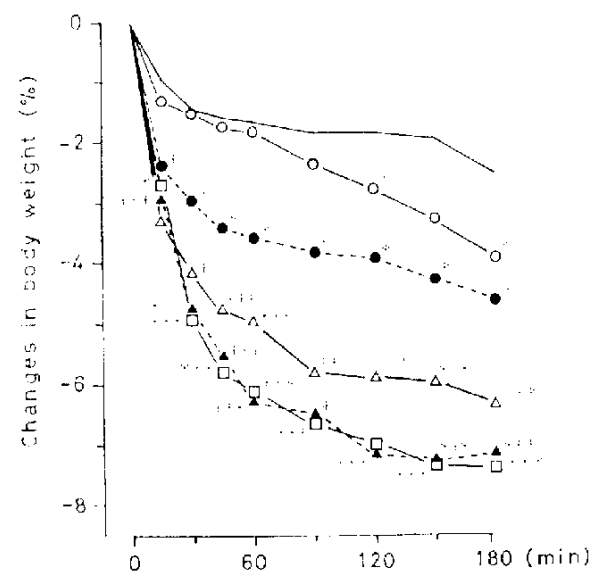

Fig. 1. Changes in body weight after naloxono challenge $(3.0 \mathrm{mg} / \mathrm{kg}, \mathrm{s.c}$.). The ordinate shows percent changes in body weight of the groups; control (- ) : Morphine: $0.0625 \mathrm{mg} / \mathrm{g}$ food (-O-), $0.125 \mathrm{mg} / \mathrm{g}$ food (--)--). $0.25 \mathrm{mg} / \mathrm{g}$ food $(-\Delta-), 0.5 \mathrm{mg} / \mathrm{g}$ food $(--\mathbf{A}--)$ and $1.0 \mathrm{mg} / \mathrm{g}$ food (-1..1-): the abscissa, time course (min) of the experiment. Each point represents a mean of 6 animals. $* P<0.05,{ }^{* *} P<0.01,{ }^{* *} P<0.001$ as cumpared to the control.

Table 1. Withdrawa! signs induccd by naloxone $(3.0 \mathrm{mg} / \mathrm{kg}$. s.c.)

\begin{tabular}{|c|c|c|c|c|c|c|}
\hline \multirow{2}{*}{$\begin{array}{l}\text { Willidrarrai } \\
\text { signs }\end{array}$} & \multicolumn{6}{|c|}{ Groups of rats treated with morphine (mg/g food) } \\
\hline & $\begin{array}{c}\text { Control } \\
(6)\end{array}$ & $\begin{array}{c}0.0625 \\
(6)\end{array}$ & $\begin{array}{c}0.125 \\
(6)\end{array}$ & $\begin{array}{l}0.25 \\
(6)\end{array}$ & $\begin{array}{l}0.5 \\
(6)\end{array}$ & $\begin{array}{l}1.0 \\
(6)\end{array}$ \\
\hline Diarrhea & - & $f$ & $+-+i^{-}$ & $+t+$ & $++t$ & +++ \\
\hline Ptosis & + : & $:+1$ & $1 \cdot 1$ & $\frac{1}{2}++$ & $+-t$ & +++- \\
\hline Teeth-chattoring & + & $+\dashv$ & $++t$ & +++ & ++4 & +++ \\
\hline Irritability & + & +1 & $\dashv$ & +1 & $+1+1$ & $++t$ \\
\hline Vocalization & - & ++ & +++ & +++ & +++ & $1+1+$ \\
\hline Aggression & $-\cdots$ & - & - & + & + & ++ \\
\hline Salivation & $\ldots$ & -. & & ++ & ++ & +-+ \\
\hline Nose-bloed & - & - & - & + & ++ & ++ \\
\hline Lacrimation & - & - & - & - & 14 & +++ \\
\hline
\end{tabular}

+++ sign prosent in $100 \%$ of animals. ++ sign present in $50-99 \%$ of animals, + sign present in $1-49 \%$ of animals. - sign absent. Numbers of rats are indicated in parentheses. 
Changes in body weight observed in each group following naloxone challenge are shown in Fig. 1. In animals treated with morphine $(0.125,0.25,0.5$ and $1.0 \mathrm{mg} / \mathrm{g}$ food), drastic losses of body weight were observed within $30 \mathrm{~min}$ after naloxone administration, and the decreases continued during the experiment. Animals treated with a low dose of morphine $(0.0625 \mathrm{mg} / \mathrm{g}$ food) showed a significant loss of body weight following $120 \mathrm{~min}$ of naloxone treatment. although no marked changes in body weight compared with the control were observed within $60 \mathrm{~min}$. The extent of these significant losses of body weights was also correlated with the morphine doses.

2. Effects of morphine on the excretion of urinary proteins: Urinary proteins of male rats were electrophoretically divided into two major groups according to molecular size: albumin and LMWP that consists of several proteins.

The changes in urinary excretion of LMWP

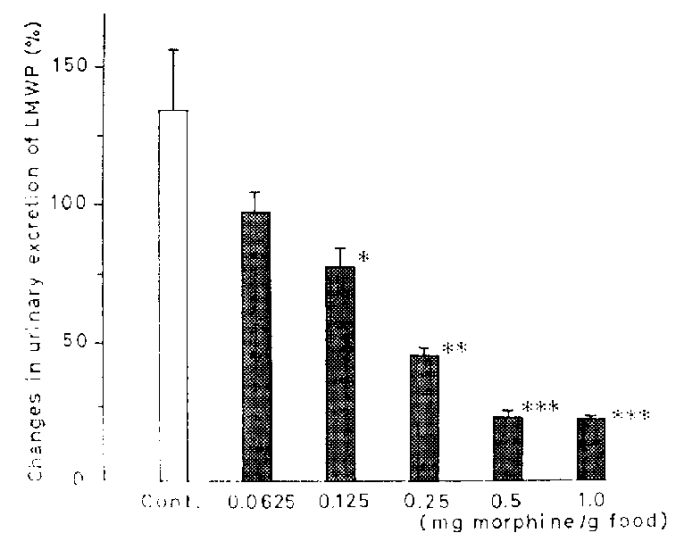

Fig. 2. Changes in urinary excretion of LMWP on the 7th day after chronic treatment with several doses of morphine. The urinary basal levels of LMWP expressed as $\mathrm{mg}$ LMWP/mg creatinine for each group are 1.232 \pm 0.228 , (contro!): $1.268 \pm 0.106$. (0.0625 mg morphine/g food): $1.359 \pm 0.107$. $(0.125 \mathrm{mg} / \mathrm{g}$ food $): 1.834 \pm 0.164,(0.25 \mathrm{mg} / \mathrm{g}$ food); $1.790 \pm 0.159 .(0.5 \mathrm{mg} / \mathrm{g}$ food) and $1.746 \pm 0.142$. $(1.0 \mathrm{mg} / \mathrm{g}$ food). Each column and respective vertical bar represents the mean $\pm S$.E. of 6 animals. " $P<0.05$. ${ }^{* *} \mathrm{P}<0.01,{ }^{* *} \mathrm{P}<0.001$ as compared to the control. after chronic treatment with some doses of morphine are shown in Fig. 2. Significant decreases in urinary excretion of LMWP compared with the control were observed on the 7 th day after the treatment with morphine $(0.125,0.25,0.5$ and $1.0 \mathrm{mg} / \mathrm{g}$ food). The decreased levels of LMWP at the above doses were $23.0,55.5,76.5$ and $77.9 \%$ of the pre-medication levels, respectively. In animals treated with the lowest dose of morphine $(0.0625 \mathrm{mg} / \mathrm{g}$ food), the urinary excretion of LMWP was recognized to tend to decrease. but showed no statistical significance. These decreases of urinary LMWP excretion after chronic treatment with morphine were dosedependent.

On the contrary, there was no significant difference in albumin excretion between the control and the animals treated with each dose of morphine on the 7th day (Fig. 3).

3. Statistical analysis of the relationship between the decrease in urinary LMWP excretion and body weight loss after naloxone

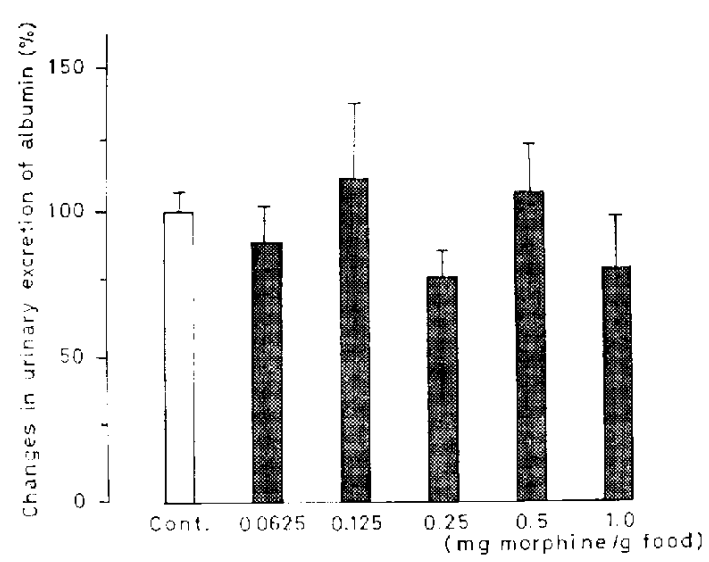

Fig. 3. Changes in urinary excretion of albumin on the 7th day after chronic treatment with several doses of morphine. The urinary basal levels of albumin expressed as $\mu \mathrm{g}$ albumin/mg creatinine for each group are $31.12 \pm 2.75$, (control); $31.81 \pm 8.65$. (0.0625 mg morphine/g food): $33.65 \pm 7.12,(0.125$

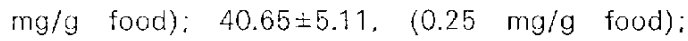
$35.10 \pm 2.23,(0.5 \mathrm{mg} / \mathrm{g}$ food); and $33.65 \pm 7.12$. $(1.0 \mathrm{mg} / \mathrm{g}$ food). Each column and respective vertical bar represents the mean $\pm S$. E. of 6 animals. 


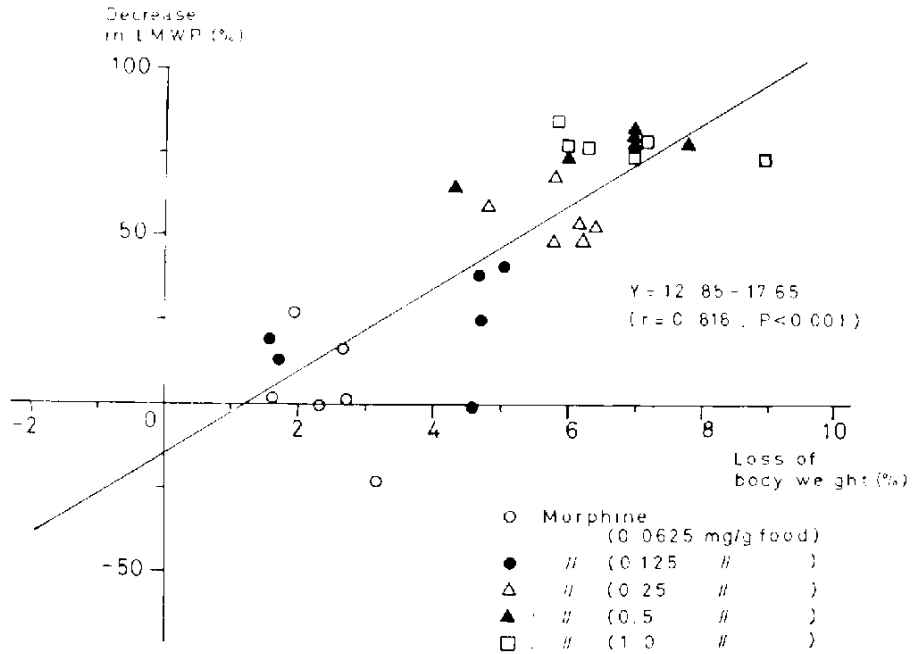

Fig. 4. Correlation between body werght loss and decrease in urinary excretion. The body weight loss is shown as the percent change in body weight at 90 min after naloxone challenge. The decrease in urinary LMWP excretion is expressed as the percent change of LWWP on the 7 th day following the treatment with several doses of mophine as given in Fig. 2

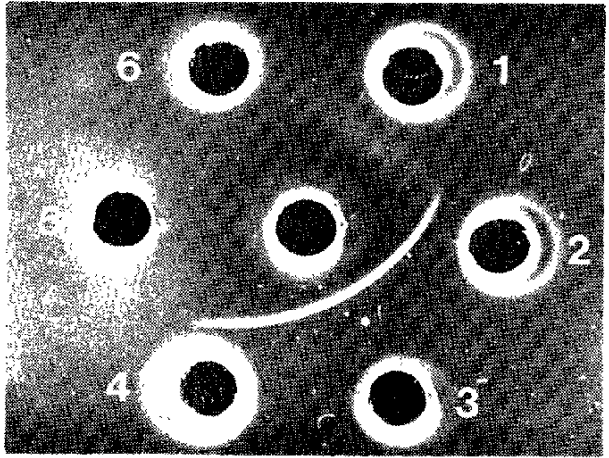

Fig. 5. Double diffusion Ouciterlony plate of tissue extracts from malc rats ircubated with the specific antiserum against urinary LMWP. The center well contained the specific antiserum. 1. Liver 2. Spleen 3. Kidney 4. Tostis 5. Somina! vosicle 6. lung

treatment: Each body weight loss at 90 min after naloxone challenge was used in this analysis since the body weight loss reached a plateau from 120 min following naloxone treatment in animals treated with morphine (0.25, 0.5 and $1.0 \mathrm{mg} / \mathrm{g}$ food) (Fig. 1). As shown in Fig. 4, a straight line with a high correlation coefficient and statistical significance was obtained when the percent loss of body weight was plotted against tho

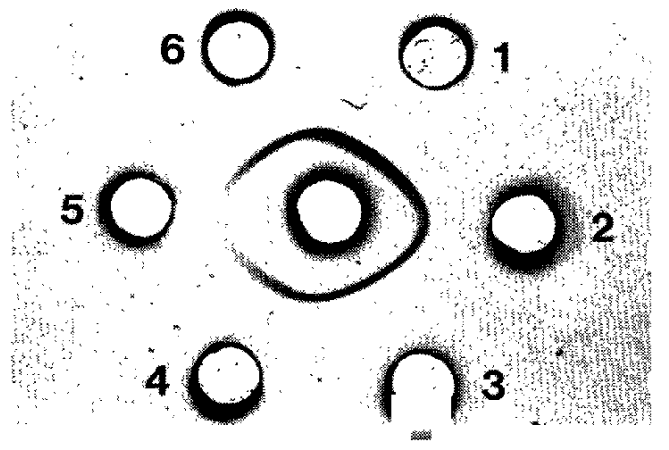

Fig. 6. Ouchterlony plate showing changes in LMWP contents of the kidney and serum following crronic administration of morphine. The center well contained the spccific antiserum against LMWP. 1. Kidney extract from the control rat $(5 \mathrm{mg} / \mathrm{ml}$, protein amount). 2. Serum from the control $(60 \mathrm{mg} /$ mi). 3. Serum from the control 6 hr after bilateral mephrectomy $(60 \mathrm{mg} / \mathrm{ml})$. 4. Kidnoy axtract from the animal treated with morohine $(5 \mathrm{mg} / \mathrm{ml}) .5$. Serum from the animai treated with morphine (60 $\mathrm{mg} / \mathrm{ml}$. 6. Serum from the animal troated with: morphine 6 hr after bilatera! nephrectomy $(60 \mathrm{mg} / \mathrm{ml})$

percent decrease in LMWP on the 7th day after morphine treatment.

4. Distribution of LMWP in various organs: The presence of urinary LMWP was tested in 
various tissue extracts using a double diffusion Ouchterlony plate. Although no precipitin line was developed with various tissue extracts and serum from female rats (data not shown), positive lines were obtained with the extracts of the kidney and liver at high protein concentrations (over $10 \mathrm{mg} / \mathrm{ml}$ ) and serum from male rats (Figs. 5 and 6 ). At a lower protein concentration $(3 \mathrm{mg} / \mathrm{ml})$, however, the precipitin line was observed only with the kidney extract (data not shown).

5. Changes of LMWP contents in livers, kidneys and sera after chronic treatment with morphine: In order to establish the source of LMWP production in the liver, rats were bilaterally nephrectomized. As shown in Fig. 6, the serum level of LMWP was increased following bilateral nephrectomy in both control and morphine treated rats (this result was confirmed by semi-quantitative assay using a radial immunodiffusion method). In the rats treated with morphine, however, the immunoprecipitins with extracts from livers, kidneys, and sera wero more faint than those in the control (Figs. 6 and 7). The accumulation of LMWP in the serum could be clearly demonstrated after bilateral nephrectomy following morphine treatment as well as the control (Fig. 6).

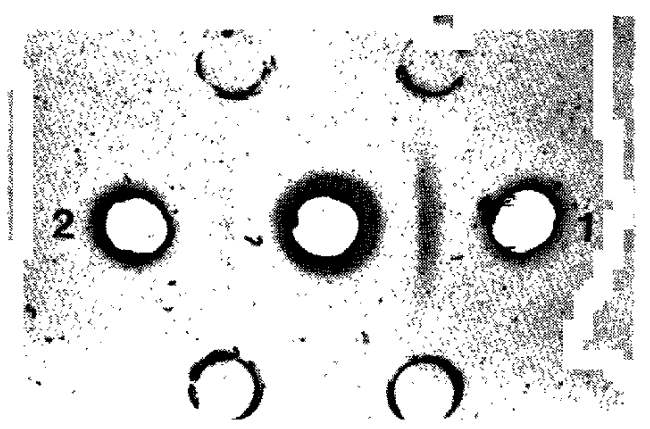

Fig. 7. Ouchterlony plate showing changes in LMWP contents of the liver folowing coronic administration of morphine. 1. Liver extec: flom the control rat $(20 \mathrm{mg} / \mathrm{ml}$; protein amounl). 2. Irver extract from the animal treated with morphine 120 $\mathrm{mg} / \mathrm{m} !)$

\section{Discussion}

The assessment of physical dependence on narcotics has been carried out using some withdrawal signs precipitated after drug withdrawal or naloxone challenge (13-16). Little attention, however, has been paid to the exploitation of methods by which the development of physical dependence on narcotics could be detected and evaluated quantitatively without requiring drug withdrawal or naloxone administration. If any physical signs specifically reflecting the state of narcotic physical dependence could be found, they might introduce a useful method for investigating the induction of narcotic dependence.

Our previous studies have shown that the urinary excretion of sex-dependent LMWP in male rats was drastically decreased after chronic treatment with narcotics. Moreover. the decrease of LMWP was closely related to the development of physical dependence (1. 2). In the present paper, we tried to clarify the relationship between decrease in urinary LMWP excretion and narcotic dependence by using morphine as a typical narcotic analgesia. As shown in Fig. 2, the urinary LMWP decrease induced by chronic administration of morphine was dosedependent. Each decrease of LMWP was well correlated to the intensity of withdrawal signs precipitated by naloxone challenge (Fig. 1 and Table 1). Furthermore, a high correlation coefficient $(r=0.818)$ was obtained between decrease in urinary LMWP excretion and body weight loss after naloxone challenge (Fig. 4). These results indicate that the dose-dependent decrease of LMWP may objectively reflect the degree of physical dependence on morphine since the loss of body weight following the drug withdrawal or naloxone challenge has been considered to be a reliable index for the assessment of narcotic physical dependence in the rat (16- 
18). On the other hand, no marked changes in urinary excretion of albumin were recognized in the chronic treatment with each dose of morphine (Fig. 3). This is in good agreement with the previous papers $(1,2)$. From the data of our previous and present studies, it can therefore be concluded that the drastic decrease in urinary LMWP excretion should be a specific phenomenon observed not only in the case of narcotic induced physical dependence, but also reflected the degree of physical dependence. In addition, we reported that the decrease of LMWP was recognized following the third day of the treatment with morphine $(0.5 \mathrm{mg} / \mathrm{kg}$ food) (1). The time course of the appearence of LMWP change was consistent with that of the development of physical dependence on morphine since Suzuki et al. (19) demonstrated that withdrawal signs including body weight loss were clearly observed from the 3 rd day after morphine administration $(0.5 \mathrm{mg} / \mathrm{g}$ food). This agreement suggests that the decrease in urinary LMWP excretion may be closely connected with the developmental process of narcotic physical dependence. From these points of view. we could speculate that the decrease in urinary LMWP excretion induced by chronic administration of narcotics should be a possible parameter by which the state of narcotic physical dependence could be assessed indirectly on the peripheral level without requiring drug withdrawal and naloxone challenge, although this parameter is limited to use only in the male rat; and the mechanism causing the decrease of LMWP can not be clarified yet.

For the purpose of elucidating this mechanism, we have initially attempted immunological studies in the present paper. The immunological data of LMWP distribution presented in Fig. 5 and the accumulation of LMWP in the serum following bilateral nephrectomy (Fig. 6) suggest that the sexdependent LMWP may be synthesized by the liver, transported to the kidneys through the serum, and then excreted into the urine. This fact is consistent with a previous report by Roy and Neuhaus (6). Furthermore, it is likely that the strongest immunological reactivity with the renal supernatant (Fig. 5) indicates the reabsorption of LMWP in the kidney. Royce (20) has demonstrated that $51 \%$ of the purified sex-dependent protein was reabsorbed following glomerular filtration, and Neuhaus and Lerseth (21) have reported that the kidney controlled the urinary excretion of $\alpha_{2 \mathbf{u}}$-globulin. a sex-dependent protein named by Roy and Neuhaus (22), by altering its reabsorption. Concerning the mechanism of the decrease in urinary LMWP excretion after chronic treatment with narcotics, an accumulation of LMWP in the kidney could be taken into account. As shown in Fig. 6, however, the LMWP concentration in the kidney supernatant was reduced in comparison with the control following morphine administration for 7 days, suggesting that the decrease in urinary LMWP excretion was not caused by the enhancement of renal reabsorption of LMWP.

The immunological reactivity with LMWP in the liver and serum of the animal treated with morphine declined as compared with that of the control (Figs. 6 and 7). Therefore, it is reasonable to speculate that inhibition of the LMWP synthesis in the liver may be associated with the decrease in urinary excretion of the proteins following chronic treatment with narcotics. As to chronic effects of morphine on the liver. Datta and Antopol (23) have reported that chronic administration of morphine produced a dosedependent decrease in the specific activity of RNA polymerase in the mouse liver. At the present time, however, it is difficult to conclude that this inhibition of RNA polymerase activity may contribute to the decrease in urinary LMWP excretion for the following reasons: The time course of the appearance of 
LMWP change is faster than that of the decrease in RNA polymerase activity in the liver. Moreover, the decreased RNA polymerase activity did not recover to the control level within 10 days following morphine withdrawal, in spite of the fact that the decreased LMWP excretion was restored to normal within 7 days after the withdrawal (1).

The hepatic synthesis of $\alpha_{2 u}$-globulin in male rats has been reported to be under the complex control of such hormones as androgens. glucocorticoids, thyroid hormones, and pituitary growth hormone (24-27). Therefore, it is necessary to investigate the relationship between the hormonal action and inhibition of hepatic LMWP synthesis by narcotics since effects of narcotics and endogenous opioid peptides on endocrine functions have been well known (28). At present, we have obtained evidence indicating that androgens and glucocorticoids do not play an important role in the LMWP decrease induced by chronic narcotic treatment (unpublished data).

Experiments are in progress to study whether the inhibition of hepatic LMWP synthesis by morphine is due to direct action or through more complex pathways.

Acknowledgments: The authors are grateful to Misses M. Yoshida, K. Kurosaki. $M$. Koizumi and $K$. Kondou for their excellent technical assistance and to Miss M. Nakano for preparing this manuscript. This study was supported in part by grants from the Japanese Ministry of Education. Science and Culture (No. 56370009, 56370019 and 57570069) and by the Foundation for the Promotion of Reseach on Medicinal Resources.

\section{References}

1) Akiba, I., Endou, H., Suzuki, T., Yanaura, S. and Sakai, F.: Relationship between chronic treatment with morphine and sex-dependent low molecular weight protein excretion. Life Sci. 29, 1057-1063 (1981)
2) Akiba, I. Endou, H. and Sakai, F.: Effect of narcotics on the excretion of sex-dependent low molecular weight proteins (LMWP) in male Wistar rats. Abstracts of 8 th Int. Cong. Nephrol., Athens, p. 183 (1981)

3) Roy, A.K., Nouhaus, O.W. and Harmison, C.R.: Preparation and characterization of a sexdependent rat urinary protein. Biochim. Biophys. Acta 127, 72-81 (1966)

4) Lane, S.E. and Neuhaus, O.W.: Furthor studies on the isolation and characterization of a sexdependent protein from the urine of male rats. Biochim. Biophys. Acta 257, 461-470 (1972)

5) Geertzen, H.G.M., Ouderaa, F.J.G.v.d. and Kassenaar, A.A.H.: Isolation and metabolism of male sex-dependent urinary protein from rats. Acta Endocrinol. (Copenh.) 72, 197-208 (1973)

6) Roy, A.K. and Neuhaus, O.W.: Proof of the hepatic synthesis of a sex-dopondont protoin in the rat. Biochim. Biophys. Acta 127, 82-87 (1966)

7) Yanaura, S., Tagashira, E. and Suzuki, T.: Physical dependence on morphine, phenobarbital and diazepam in rats by drug-admixed food ingestion. Japan. J. Pharmacol. 25, 453-463 (1975)

8) Maggiolo, C. and Huidobro, F.: Administration of pellets of morphine to mice: abstinence syndrome. Acta Physiol. Lat. Am. 11, 70-78 (1961)

9) Way, E.L., Loh, H.H. and Shen, F.: Simultaneous quantitative assessment of morphine toleranco and physical dependence. J. Pharmacol. Exp. Ther. 167, 1-8 (1969)

10) Endou, H., Kimura, K., Sudo, J. and Sakai, F.: Quantitative analysis of electrophoretically separated proteins using coomassie blue. Japan. J. Exp. Med. 48, 297-301 (1978)

11) Ouchterlony, O.: Diffusion-in-gel methods for immunological analysis. In Progress in Allergy. Edited by Kallós, P., Vol. V. p. 1-78, Karger. Basel and New York (1958)

12) Lowry, O.H., Rosebrough, H.J., Farr, A.L. and Randall, R.J.: Protein measurement with the folin phenol reagent. J. Biol. Chem. 193, 265275 (1951)

13) Blaesig, J., Herz, A., Reinhold, $K$. and Zieglgaensberger, S.: Developmont of physical dependence on morphine in respect to time and dosage and quantification of the precipitated withdrawal syndrome in rats. Psychopharmacologia (Berlin) 33, 19-38 (1973)

14) Martin, W.R., Wikler, A., Eades, C.G. and Pescor, F.T.: Tolerance to and physical dependence on morphine in rats. Psychopharmacologia (Berlin) 


\section{4, 247-260 (1963)}

15) Kumar, R., Mitchell, E. and Stolerman, I.P.: Disturbed patterns of behavior in morphine tolerant and abstinent rats. Br. J. Pharmacol. 42, 473-484 (1971)

16) Hosoya, E.: Some withdrawal symptoms of rats to morphine. Pharmacologist 1,77 (1959)

17) Wei, E. and Way, E.L.: Application of the pellet implantation technique for the assessment of tolerance and physical dependence in tho rodent. In Mothods in Narcotics Research. Edited by Ehrenpreis, S. and Neidle, A., p. 243259. Marcel Dekker Inc. New York (1975)

18) Nozaki, M.: Assessment of morphine-type physical dependence; a screening method using the rat. Psychopharmacology (Berlin) 47, 225235 (1975)

19) Suzuki, T., Shimada, M., Yoshii, T., Uesugi, J. and Yanaura, S.: Development process of physical dependence and tolerance in rats treated with morphine admixed food. Prog. Neuropsychopharmacol. 7, (1983) (in press)

20) Royce, P.G.: Characterization of a renaldependent rat serum protein. Am. J. Physiol. $215,1429-1434$ (1968)

21) Neuhaus, O.W. and Lerseth, D.S.: Dietary control of the renal reabsorption and excretion of $\alpha_{2 n}$-globulin. Kidney Int. 16, 409-415 (1979)

22) Roy, A.K. and Neuhaus, O.W.: Identification of rat urinary proteins by zone and immunoelectro- phoresis. Proc. Soc. Exp. Biol. Med. 121, 894$899(1966)$

23) Datta, R.K. and Antopol, W.: Inhibitory effect of chronic administration of morphine on RNA polymerase activities of mouse liver and brain nuclei. Toxicol. Appl. Pharmacol. 25, 71-76 (1973)

24) Roy, A.K. and Neuhaus, O.W.: Androgenic control of a sex-dependent protein in the rat. Nature 214, 618-620 (1967)

25) Irwin, J.F., Lane, S.E. and Neuhaus, O.W.: Synergistic effect of glucocorticoids and androgens on the biosynthesis of a sexdependent protoin in the male rat. Biochim. Biophys. Acta 252, 328-334 (1971)

26) Roy, A.K.: Androgen-dependent synthesis of $\alpha_{21 \mathrm{t}}$-globulin in the rat; role of the pituitary gland. J. Endocrinol. 56, 295-301 (1973)

27) Feigelson, P., Chen, C.-L.C., Kurtz, D.T. and Chan, K.-M.: Studies on the multihormonal pretranslational, translational and posttranslational regulation of $\alpha_{211}$-globulin synthesis. In The Induction of Drug Metabolism. Edited by Estabrook. R.W. and Lindenlaub. E., p. 2563. F.K. Schattauer Verlag. Stuttgart and New York (1979)

28) Meites, J., Bruni, J.F., Vugt, D.A.V. and Smith, A.F.: Relation of endogenous opioid poptides and morphine to neuroendocrine functions. Life Sci. 24, 1325-1336 (1979) 